\title{
сошиопогия
}

\author{
Barbara POGONOWSKA ${ }^{1}$
}

UDC 662.5

\section{INTERPRETATIONS OF ANTI-GLOBAL SOCIAL MOVEMENTS FROM THE PERSPECTIVE OF ETHICS ECONOMY REFLECTION}

\author{
1 Ph. D., Associate Professor, \\ Department of Sociology and Business Ethics, \\ Poznan University of Economics and Business (Poland) \\ barbara.pogonowska@ue.poznan.pl
}

\begin{abstract}
The main interests of the article are the social movements and oppositions, which have emerged during and after the financial crisis of 2008. The social events like Wall Street Occupy, Fight for \$15, or Make Poverty History can be perceived as a very interesting form of resistance to the capitalistic system of economy. The major objective is to recognize the plurality of interpretations of the cultural context and the role of these grassroots movements. That plurality is a consequence of axiological assumptions related to the concept of society. The other goal of such considerations is to expose that grassroots movements may cause some social changes within the sphere of economy according to current social expectations. The article attempts at presenting a culture-oriented approach that implies the constructivist vision of society. The methodology of constructivism includes the method of qualitative research such as humanistic interpretation of social beliefs developed by Jerzy Kmita.
\end{abstract}

\section{Keywords}

Anti-global protest, axiological assumptions, ethics, grassroots movements, UN Global Compact, balanced and sustainable development, individual and common values.

Citation: Pogonowska B. 2019. "Interpretations of anti-global social movements from the perspective of ethics economy reflection". Tyumen State University Herald. Social, Economic, and Law Research, vol. 5, no 3 (19), pp. 8-22.

DOI: $10.21684 / 2411-7897-2019-5-3-8-22$ 
DOI: $10.21684 / 2411-7897-2019-5-3-8-22$

\section{Introduction}

This article describes normative assumptions of statements interpreting the meaning of contemporary social movements and protests, as well as anti-system movements whose appearance is connected with the outbreak of the financial crisis of 2008. These assumptions will be identified from the perspective of the culturally understood reflection on ethics economy, i.e. socio-regulatory theory of J. Kmita, who implies the constructivistic vision of society based on humanistic interpretation qualitative method. The criteria of ethical analysis have been reduced to the content of Global Compact postulates and the idea of sustainable development. The results of the performed reconstruction of protests of an anti-global character are supposed to form the basis for the assessment of the extent to which the valuations present in the relevant statements can be applied by the global ethical reflection on management. At the same time, this paper attempts to answer the question whether the events of the last few years (mentioned in the text) have a fleeting nature - they do not have an impact on socio-economic life - or whether their consequences can be traced not only in the form of changes in social awareness but also the effects of global and local socioeconomic practice.

\section{Examples of anti-global protests and social movements}

Without going deeper into the terminological considerations related to these events, I will refer to the concept of Piotr Sztompka, who defines social movements as types of activities that have two distinguishing characteristics: "First of all, they are aimed at the specific objective that is to achieve some kind of social change. And secondly, they take place in a non-institutionalized and non-formalized framework..." [21, p. 158; our transl.]. According to P. Sztompka, the rise in the number of these activities means that contemporary societies are increasingly becoming "the communities of social movements" and especially the anti-globalization movements focused around economic goals, which, however, do not defend the individual interests of particular classes or professional groups, but act "on behalf of 'ordinary people' against the demonized world of big business and finance, became the phenomenon of the turn of the $20^{\text {th }}$ and $21^{\text {st }}$ centuries" [21, p. 164; our transl.].

A more general characteristic is proposed by Anthony Giddens, who believes that the social movement is "a large group of people involved in implementing or blocking the process of social change [which] usually operate in opposition to the organizations whose aims and views they disagree with" [10, p. 1011-1012]. Let us assume that, according to this definition, the text will focus on the actions aimed at expressing opposition to economic and cultural globalization and at the functioning of economic and political entities which are responsible for the processes that cause a systematic decline in the share of wages in the value of goods produced, the formation of unfair labor market rules, the worsening of social disparities, in- 
cluding income inequalities, and the socially dangerous financialization of the economy among others.

As the matter of fact, there is no justified argument for the selection of the social movements that are described in what follows. The only one criterion for the specific cases selection is the level of theirs public popularity. One of the most spectacular manifestations of social discord on the situation and difficult material situation caused by the financial crisis of 2008 is the Global Outraged Movement (The Indignados Movement). The name of the movement refers to the title of the 13-page brochure entitled Time for Outrage! (Indignez-Vous!), published in 2010 by Stephane Hessel [11], a French poet and diplomat. As Hessel says in his interview, "In the booklet I write that societies should mobilize to find solutions to the huge problems of modern world. The most important of these is the unimaginable poverty of millions in contrast to the scandalous wealth of a few. This is the result of the fact that the resource redistribution system works badly" [7, p. 23; our transl.]. The first demonstration of the Outraged Movement (Indignados) took place in May 2011 in Madrid, Puerta del Sol, in response to the announcement of a 5\% salary cut in the public sector. The protesters stayed on the streets for several months in a spontaneously built small town, expressing their disagreement with the social consequences of the financial crisis and the corruption of the world of politics, business, and banking. Protests of the same nature also emerged in other cities in Spain (tens of thousands of people in total), as well as in France, Italy, Greece, Scandinavia, New York, and London. As S. Žižek says in 2012:

"Yes, the protests did create a vacuum — a vacuum in the field of hegemonic ideology, and time is needed to fill this vacuum in in a proper way, since it is a pregnant vacuum, an opening for the truly New" [27].

Wall Street Occupy / Occupy Wall Street (OWS) is the protest, which originates from the Global Outraged Movement. The first demonstrations took place on 16 July 2011 in Zucotti Park in New York under the slogans of protest against the global omnipotence of money and racial and sexual discrimination, against wars (pacifists), environmental degradation, wrongly convicted prisoners, and in the name of the fight for women's rights [26, p. 89]. The square in front of St. Paul's Cathedral in the City became the venue for weeks-long protest of the Outraged in London in 2011.

The protests under the slogan "war on one percent" (against 1\% of the richest) and the phenomenon of the global movement Anonymous, which opposed, among other things, the intention to introduce ACTA in January 2012, are also worth mentioning.

In 2011 and 2012, student protests, being the part of the Global Outraged Movement, took place in Chile. Their specificity was to focus their demands on free education and the reform of the entire educational system (Chile occupies a distant place in the world rankings in terms of the level of education).

Another social movement is the rebellion of 60,000 of McDonald's and other fast food employees who left their workplaces in November 2012 in more than 200 US 
cities to fight for an increase in the minimum hourly rate. Fight for $\$ 15$ with the slogan "Hey, hey we demand fair pay", they spoke on behalf of $5.6 \mathrm{mln}$ people employed in the service sector and earning statutory (federal) minimum $\$ 7.25$ per hour.

An interesting example of global social protests is also the Den Plirono movement, launched in Greece in 2012 ("I refuse to pay"). The participants of this initiative disagree by refusing to pay taxes, public transport or motorway fees due to the excessive amount of these fees in connection with low incomes of its residents. This movement also has its counterpart in Spain. Another form of protest was the Account Closing Day announced in the USA in November 2012. In the act of disagreement with the increase in customer account fees introduced by commercial banks, a massive transfer of savings from these banks to local savings banks was called for.

On 31 May 2013 in Taksim Square in Istanbul (Turkey), a demonstration took place against the special development plans for the Gezi Park. The demonstrations, initially targeted at developers, quickly turned into a protest against the authoritarian policy of Prime Minister Redjep Tajjip Erdgan and spread throughout the country. Several people were killed and several hundred injured in clashes with the police. The protests were suppressed after a few weeks. The plan to transform the park in the center of Instanbul into a shopping mall was considered by the residents as an attempt to appropriate a common public space. The most serious reason for such protests, dramatic both in the course and their consequences, is the participants' awareness that free market fundamentalism and Islamic fundamentalism in the version of Islamic authoritarianism are linked by the common interests [22].

Another example is the Nuit Debout movement (Up All Night), initiated by director Francois Ruffin's call to organize night debates, starting on 31 March 2016 in Paris (later also in Bordeaux and Toulouse, among others) under the slogan of "the repair of the Republic" as a part of his opposition to the government's reform of the labor code: "People who support the Nuit Debout movement want to create something that will be controlled not by politicians but directly by themselves [19, p. 10; our transl.].

The social movement Make Poverty History, initiated by the events of July 2005 in Edinburgh, is still an active project aimed mainly at the problems of sub-Saharan African society caused by economic globalization. Its representatives demand, among other things, an increase in aid from the EU Member States to the region and counteracting corruption in the oil sector.

An example of social movements, created as a result of the financial crisis of 2008 in Poland, are the protests of artists (avant-garde precariat). In 2011, the National Movement of Citizens of Culture was established, which in the Pact for Culture 2011 protest program expressed its opposition to the precarization of the field of art by demanding negotiations on wage issues with public cultural institutions, as well as to the intervention in employee matters in individual cases of violation of creative rights by employers and clients [2, p. 9].

Certainly, attention should be paid to the so called urban movements which have been developing in Poland for several years; they are not always tangible or visible, 
but less and less understated, as reflected by the successes of the activists in the local government elections. The protests of the "locally outraged" are of a similar nature: these are e.g. the residents of housing estates who express their disagreement with the unfavorable decisions of developers supported by local authorities, or finally — the so-called tenant movements, defending citizens against evictions and expropriation.

To summarize this part, let us use two statements, valid from the point of view of contemporary events:

"These various protests of 2011 can be seen as a phase preceding each and every transformation characterized by what historians, such as E. Hobsbawm, referred to as 'primary rebellions'. What they meant there were the activities of groups or individuals who know what they oppose, but are not sure what they want in return. This was the case at the beginning of the nineteenth century among the luddites, and at the beginning of the twentieth century for the anarchists and the likes" [21, pp. 24-25; our transl.].

Piotr Czapliński made a remark in relation to the acceptance of violence in contemporary literature: rebellion, protest or revolt is an immediate concentration of social energy and the birth of a temporary collective subject, a demonstration of determination in some common matters concerning what is pragmatically effective and morally good [3].

\section{Areas of events interpretation}

Zygmunt Bauman states that

"so far, there is no evidence of its [model of grassroots democracy] effectiveness. I keep on repeating on and on that the Occupy Wall Street movement was noticed both by the journalists and philosophers, just Wall Street was not aware of being occupied. It all goes as usual: bankers pay themselves huge severance pays, shareholders take huge dividends. Nothing has changed" [17, p. 9; our transl.].

Most comments on the importance of contemporary global social protests can be found in the statements of the activists of the critical emancipatory trend (leftwing, post-Marx or socio-democratic stances), which in Poland is significantly represented by the community of "Political Criticism" that states on the publisher's website that their "goal is to introduce and strengthen in the public sphere the leftwing project of combating economic and cultural exclusion". However, given the broader intellectual context, the reference to two types of ideas deserves some consideration.

On the one hand, it is important to refer to the Critical Theory of the Frankfurt School, including the derived discourse theory of Michel Foucault, and in particular 
to the analyses related to the study of systems of discourse marginalization and any forms of eliminating beliefs from public space. According to M. Foucault,

"instead of seeking first and foremost what is accepted, recognized or valued by society, I ask myself and constantly wonder whether it would not be more interesting to look for what is rejected and excluded from society and from the system of thinking. What ideas, behaviors, deeds, legal or moral principles are not recognized, cannot be recognized and thus are excluded from the system" [8, p. 79; our transl.].

"The analyses that I undertake, following these principles and referring to this perspective, are divided into two groups. On the one hand, it is a 'critical' category, in which the principle of reversal is applied: an attempt to capture forms of exclusion, limitations of adaptation $<\ldots>$; showing how they are formed, which needs they respond to, how they have been modified and moved, which coercion they have used, to what extent they have been reversed. On the other hand, there is a 'genealogical' category, which follows three different principles: how, through these coercive mechanisms, against them or with their help, the series of discourses were formed; what was the proper norm for each of them and what were the conditions for their formation, growth and emergence of their varieties" [9, p. 43].

These two extensive quotations undoubtedly emphasize the importance of conducting analyses of even ephemerally appearing discourses (here: postulates characteristic of the discussed global events) that appear on the margins of the official or dominant way of perceiving the social world because they express the emerging "anxieties" of a given culture or even already conceptualized values-the sense of community [15, p. 51].

Another interesting statement is that of a culture expert who, analyzing the notion of popular culture, introduces the term "criticality" understood as "a deep and not limited to a superficial analysis of individual 'problems' distrust in relation to the dominant ideological paradigm within which or under whose influence the meanings constituting the content of what we call" [6, p. 37; our transl.] competent, legally valid normal are determined.

On the other hand, it is important to refer to those emancipatory and critical ideas which, according to the Oxford Learner's Dictionaries' definition, are connected with actions for liberation, freeing somebody from any oppression, dependence or subordination of individuals and groups especially from legal, political or social restrictions $[14$, p. 119]. However, before we move on to the interpretation of the discussed events, it is worth to provide examples of practically tangible effects in the public sphere achieved as a result of global social protests: the Outraged Movement in Spain won two Parliamentary seats; the Outraged Movement in Chile — one seat in Parliament; as a result of the Account Closing Day, several large banks abolished controversial fees; Fight for $\$ 15$ resulted in the introduction of a higher than statutory minimum 
wage in twenty-one US states; salaries were also raised by Walmart, Gap, and Ikea; the introduction of the so-called minimum guaranteed income in Brazil (Bolsa Familia); discussions have begun on the project of the so-called Citizen Basic Income (everybody, regardless of their material situation, receives the minimum subsistence amount); the OWS activists calculated that "since the beginning of the protect, the mainstream media have used the word social injustice five times more often than before. We have to start somewhere" [26, p. 90; our transl.].

\section{Interpretive diversity}

As it could have been expected, interpretations belonging to concepts of discourses and critical emancipatory trends mentioned above are not homogeneous in the sense of the meaning given to the presence of contemporary social protests. The view of Javier Cercas, who fears that these events will be fleeting and short-lived, is the example of a statement expressing skepticism: "The storm will pass and nothing will change. The economy will recover and everything will remain unchanged. This will become dangerous, as it will mean that the solution has been postponed". Octavio Paz, when communism collapsed, said "bad answers fell, but good questions remained" [4, p. 27; our transl.]. Guy Standing, on the other hand, points to the threat of diminishing the significance of these events in the perspective of the dominance of neoliberal discourse:

"Meanwhile, politicians and think tanks treat the precariat as a 'subclass', as a desperate group on the fringes of society that needs to be 'reintegrated' and trained, made 'employable', 'pushed', sanctioned, treated with 'raw love', subjected to cognitive-behavioral therapy, etc.” [20, p. 25].

Another group of interpretations of the meaning of grassroots movements is represented by statements that attempt to explain the sources or context of these events. According to Jan Sowa, they are "not public or private, but social. Today it is a modern way out of this opposition" [16, p. 16; our transl.]. J. Cercas believes that "solutions lie in legal regulations, but their matrix is cultural. The loss of faith in humanistic, supra-individual and social values is common. The cult of immediateness, profitability, gain, appetite satisfaction is ever-present" [4, p. 27; our transl.]. Artur Domosławski, on the other hand, reminds us that

"there is this well-known statement of the German sociologist Ulrich Beck: let us not look for individual answers to social challenges on a global scale. The architects of our economic reality have been telling us for three decades, more or less since Thatcher and Reagan times, that individual responses to various social maladies must be found. It means that if you conduct yourself in a proper way and work hard, you will succeed. The history of capitalism shows that this is not the case. That you can conduct yourself in a proper way, work hard and remain poor" [5; our transl.].

I believe that it is worthwhile to notice, in the multitude of interpretations available, the threads of statements that in global protests recognize the presence of 
social change projects of a political and local dimension, the intentions of global transformations of the capitalist system and the content of a declarative ethical character $[24 ; 12]$.

And so, the political dimension of these projects is noticed by Edwin Bendyk and Marta Mazuś, pointing to their minimum program, i.e. emerging demands for participation in political decisions, appeals for transparency, direct democracy, and access to public information, influence on shaping decisions at local and national level and depoliticizing of the political system (JOW) [1, p. 29]. On the other hand, Katarzyna Szafraniec's sociological research leads to the following conclusion: "Outrage has been growing for years". Among young people, there is a growing dislike for political elites and privileges consisting, among other things, in the distribution of public funds to groups that, in their opinion, do not deserve them [1, p. 29]. The above comments prove that the commentators have noticed that the participants of the protests disagree with the current understanding of social justice. Explicite political dimension of events is noticed by G. Standing: "the struggle for recognition is getting better, but the struggle for representation has barely begun. The recent riots in English cities in the summer of 2011 were a form of collective protest - anomic, but at least partly political in character" [20, pp. 24-25]. Z. Bauman, however, is skeptical about this issue: although the loss of faith in state authorities results in people themselves taking certain initiatives as the form of protest against violence or injustice (Bauman signed, among others, a petition on harassed tenants in Poznań at Stolarska street) and these grass-roots forces of the so-called grassroots movements are very active but there is a problem with their effectiveness in achieving their goals [17].

The local dimension of the events is present in the interpretation of Richard Florida, who states that

"Ronald Ingleton noted that today it is usually easier to gather people around public goods - ecology, green energy - rather than around traditionally understood group interests. Occupy Wall Street refers to the ideals of equality. That is obviously right. Nevertheless, people do not buy it. More people would come to defend clean air" [18, p. 119; our transl.].

The next statement contains a similar interpretation:

"There are many such locally outraged people. They are often hurt by their longstanding struggle with the 'system', discouraged by the difficulties in running their own business, engaged in disputes with institutions in personal matters or for the benefit of the community in which they live" [1, p. 29; our transl.].

Slavoj Žižek's view is characteristic of his demands for the transformation of global capitalism and social change:

"Do the problems and protests that have arisen in recent years signalize the impending global crisis, or are they just small obstacles that can be tackled by local interventions? The most remarkable feature of these outbreaks is that 
they occur not only in the weak points of the system, but also in places that have so far been regarded as examples of success. We know why people demonstrate in Greece or Spain, but why do they protest in fast-developing countries such as Turkey, Sweden and Brazil? In countries that were considered paradise. $<\ldots>$ Protests, with all their diversity, are a reaction to different aspects of capitalist globalization" [27].

According to S. Žižek, this direction implies further expansion of the market, "stealthy" privatization of public space, reduction of public services (health care, education, culture), and increase of authoritarian power. Overall, according to Žižek, the events observed are protests and revolts against the structural flaws of global capitalism, which are "sustained by a combination of overlapping demands. They fight against authoritarian regimes for ("normal", parliamentary) democracy, against racism and sexism, especially against immigrants and refugees, against corruption in politics and business (pollution of the environment by industry, etc.), for the welfare state against neoliberalism and for the new forms of democracy, reaching beyond multi-party rituals" [27]. Perhaps the social economy entities that introduce some variations within the rules of global and local dimensions of free market economy could be the one of the solutions for those social and economic problems. As Anna Waligóra states, "social enterprises focus on the people who do not find themselves in (its) neo-liberal formula" [25, p. 30; our transl.].

The statements made by Gregory Jackson, who asks the question: "Do we have some kind of utopia as a horizon, like the communists?" are characterized by literally ethical aspects. The answer is that

"the times of globalization have diminished the role of societies and communities, given enormous power to individuals and placed them at the center of concerns. Today there are more and more questions about what it means to live next to Another Person and with Another Person. $<\ldots>$ Why shouldn't we go back to the ideals of the French Revolution? Brotherhood should become the rule, but individualism does not let it to be heard. Equality should find its rightful place, but it is killed by selfishness and rivalry. Certainly, our further struggle will not be the same as that of the old revolutions. There will be no barricades, no victory which comes overnight. There will be systematic work that will lead to a far deeper revolution - it will change culture, overthrow the old hegemony" [5; our transl.].

\section{The perspective of economic ethics}

It is easily noticeable that the description and interpretation of global social protests reveals the presence of demands concerning respect for the subjectivity and dignity of the individual and the restoration of lost citizenship. In a broader sense: the reforms of the capitalist system, changes in labor market relations, the right to participate in political decision-making, transparency of economic and social rules, respect for the 
principles of social justice, equality, solidarity, etc. These postulates are undoubtedly consistent with the basic values of the sustainable development idea and the principles included in the UN Global Compact document [23]. Let us not forget that the idea of sustainable development expresses a desire to harmoniously agree conditions and principles of economic growth with social needs (such as: improvement of the quality of life, full employment, social cohesion also in the global context: sense of security, cultural diversity) and protection of the natural environment in the name of the welfare of present and future generations. As far as the signatories of the UN Global Compact are concerned, they commit to comply with four fundamental values: protection of human rights, ensuring proper labor standards, protection of the natural environment and counteracting all forms of corruption. Thus, the demands articulated by the participants of social protests express the need for profound social changes, including the need to redraw "the relationship between the individual and the community with an indication on the solutions in which a balance between community values and individual choices would be enforced" [15, p. 212; our transl.].

\section{Conclusion}

Addressing the issue of the significance of global social protests, which emerged in the years of the financial crisis of 2008-2012 and later, cannot be associated with the formulation of any conclusions regarding the possibilities and opportunities for the implementation in the social space of the postulates for changes in the rules of functioning of contemporary societies formulated during these events. Undoubtedly, these events have been recorded in the scientific discourse and the publicist debates of intellectuals. The collection of statements interpreting these protests in the sense that they perceive the significance of these events for the transformations of global social consciousness and the recall of (few) practical and material consequences was the main objective of this text.

Instead of concluding, I will quote Z. Bauman's extensive words, the content of which can be perceived in the perspective of historical constructivism:

"If we look at the new grassroots movements, we see that we need to prove finding ways to make it possible for them not only to protest, but also to act effectively and achieve their goals. And I am truly sorry, but I was eagerly looking for evidence of such effectiveness and did not find a suitable example. So I can't honestly say that there's a future in this. $<\ldots>$ [Yet] the future is in experimentation. It will take some time to re-evaluate our thoughts on the political system. $<\ldots>$ Just don't expect any remedies from me. I look around, I try to make different diagnoses, but I am not able to formulate any golden advice concerning the future. There is no future. You will be the ones to create it" [17, p. 9; our transl.].

\section{REFERENCES}

1. Bendyk E., Mazuś M. 2015. “Archipelag Kukiza”. Polityka, no 21 (3010), 20 May. [In Polish] 
2. Górna K., Sienkiewicz K., Iwański M., Szreder K., Ruksza S., Figiel J. (eds.). 2011. Czarna księga polskich artystów. oprac. zb. [The Black Book of Polish Artists]. Warsaw: Wydawnictwo Krytyka Polityczna. [In Polish]

3. Żakowski J. 2015. "Czas horroru”. The interview of J. Żakowski with prof. Czapliński. Polityka, no 31, 29 July - 4 August. [In Polish]

4. Stasiński M. 2015. "Czasem trzeba przegrać wybory, żeby wygrać jutro". The interview of M. Stasiński with Javier Cercas. Gazeta Wyborcza, 6-7 June. [In Polish]

5. Domosławski A. 2014. "Chilijscy oburzeni: nie będzie barykad, tylko systematyczna praca". Accessed 11 October 2019. http://www.krytykapolityczna.pl/artykuly/amerykalacinska/20140423/chilijscy-oburzeni-nie-bedzie-barykad-tylko-systematyczna-praca [In Polish]

6. Drozda J. 2014. "Paradygmat emancypacyjny? O możliwym nowym zwrocie w polskim kulturoznawstwie inspirowanym tradycją CCCS". Kultura Popularna, no 1/39. Accessed 5 June 2019. http://www.academia.edu/8614010/PARADYGMAT_

EMANCYPACYJNY_O_mo\%C5\%BCliwym_nowym_zwrocie_politycznym_w_ polskim_kulturoznawstwie_inspirowanym_tradycj\%C4\%85_CCCS [In Polish]

7. Durrmeyer S., Biernat J. 2012. "Stephane Hessel. Ojciec oburzonych". Newsweek. Accessed 11 October 2019. http://swiat.newsweek.pl/stephane-hessel--ojciecoburzonych,85993,1,1.html [In Polish]

8. Foucault M. 2002. Filozofia. Historia. Polityka. Wybór pism. Warsaw: Wydawnictwo Naukowe PWN. [In Polish]

9. Foucault M. 2002. The Order of Discourse. Accessed 9 December 2019. https://www.kit.ntnu.no/sites/www.kit.ntnu.no/files/Foucault_The\%20Order\%20of\%20 Discourse.pdf

10. Giddens A. 2009. Sociology. Accessed 8 May 2019. https://ia600206.us.archive.org/15/ items/Sociology_6_edition/Sociology_6_edition.pdf

11. Hessel S. 2011. Indignez-vous! Get angry! Cry out! Accessed 9 December 2019. http://indignez-vous-indignacion.blogspot.com/p/english.html

12. Misztal B. A. 1998. Trust in Modern Societies. The Search for the Bases of Social Order. Accessed 10 December 2019. https://pdfs.semanticscholar.org/0602/5cfa3cb67675dd1cb 65fa48753ede5211163.pdf?.ga=2.203289489.1674834713.15760752171253012239.1576075217

13. Różycka Z. 2014. "O Madagaskarze napisze ktoś inny". The interview of Misza Tomaszewski with Artur Domosławski. Kontakt. Accessed 11 October 2019. Kontakt. Accessed 11 October 2019. http://magazynkontakt.pl/wp-content/uploads/2014/12/ Kontakt-26_Zielone-pojecie.pdf [In Polish]

14. Oxford Learner's Dictionary. "Emancipate”. Accessed 10 July 2019. www.oxfordlearnersdictionaries.com/definition/english/emancipate

15. Pałubicka A. 2013. Gramatyka kultury europejskiej. Bydgoszcz: Oficyna Wydawnicza Epigram. [In Polish]

16. Zieliński M. A. 2015. "Polska budzi się 40 lat za późno". The interview of Michał A. Zieliński with Jan Sowa. Gazeta Wyborcza, Saturday-Sunday 2-3 May. [In Polish]

17. Danielewski M., Wybieralski M. 2012. "Poznań to nie Facebook" Z. Bauman in the interview with M. Danielewski and M. Wybieralski. Gazeta Wyborcza, 7 December. [In Polish] 
18. Żakowski J. 2012. "Power to the Cities".The interview with Richard Florida. Niezbędnik Inteligenta Polityka, no 1, special edition, pp. 116-120. [In Polish]

19. Rębała M., Wyrzykowska K. 2016. “Oburzeni młodzi Francuzi zarywają noce”. Gazeta Wyborcza, 26 April. [In Polish]

20. Standing G. 2011. The Precariat. The New Dangerous Class. Accessed 9 December 2019. https://www.hse.ru/data/2013/01/28/1304836059/Standing.\%20The_Precariat_The_ New_Dangerous_Class_-Bloomsbury_USA(2011).pdf

21. Sztompka P. 2002. "Socjologia". Kraków: Wydawnictwo Znak. [In Polish]

22. Gazeta Prawna. 2015. "Turcja: Zamknięty dostęp do placu Taksim w Stambule. Dzisiaj rocznica protestów”. Gazeta Prawna, 31 May. Accessed 11 October 2019.

http://www.gazetaprawna.pl/artykuly/874680,turcja-zamkniety-dostep-do-placu-taksimw-stambule-dzisiaj-rocznica-protestow.html [In Polish]

23. UN Global Compact. "The Ten Principles of the UN Global Compact". Accessed 8 June 2019. https://www.unglobalcompact.org/what-is-gc/mission/principles

24. Uslaner E. 2003. "The Moral Foundations of Trust”. Paper presented at the Symposium "Trust in the Knowledge Society" (20 September, Jyvaskala, Finland). University of Jyvaskyla. Accessed 9 December 2019. https:/www.researchgate.net/ publication/228191342_The_Moral_Foundatio_of_Trust

25. Waligóra A. 2019. "Social entrepreneurship vs free market. Typology (of lack) cooperation between social economy entities and enterprises". Tyumen State University Herald. Social, Economic, and Law Research, vol. 5, no 1, pp. 23-35.

DOI: 10.21684/2411-7897-2019-5-1-23-35

26. Winnicka E. 2012. “Cztery pory oburzenia”. Niezbędnik Inteligenta. Polityka, no 1, special edition. [In Polish]

27. Žižek S. 2012. “Occupy Wall Street: what is to be done next?”. Guardian, 24 April. Accessed 9 December 2019. https://www.theguardian.com/commentisfree/ cifamerica/2012/apr/24/occupy-wall-street-what-is-to-be-done-next 


\section{Барбара ПОГОНОВСКА ${ }^{1}$}

УДК 662.5

\section{ИНТЕРПРЕТАЦИЯ АНТИГЛОБАЛЬНЫХ СОЦИАЛЬНЫХ ДВИЖЕНИЙ С ТОЧКИ ЗРЕНИЯ ОТРАЖЕНИЯ ЭТИЧЕСКИХ АСПЕКТОВ ЭКОНОМИКИ}

1 Ph. D., доцент, кафедра социологии и деловой этики, Познаньский экономический университет (Польша) barbara.pogonowska@ue.poznan.pl

\section{Аннотация}

В данной статье рассматриваются общественные движения и противостояния, возникшие во время и после финансового кризиса 2008 г. Такие социальные события, как «Захватите Уолл-стрит», «Борьба за 15 \$» или «Оставим нищету в прошлом», можно рассматривать как очень интересные формы сопротивления капиталистической системе экономики.

Основная цель статьи заключается в признании плюрализма интерпретаций культурного контекста и роли этих низовых движений. Этот плюрализм является следствием аксиологических предположений, связанных с понятием общества. Другая цель данной статьи - показать, что низовые движения могут вызвать некоторые социальные изменения в экономике в соответствии с текущими социальными ожиданиями. Для этого автор представляет культурно-ориентированный подход, предполагающий конструктивистское видение общества. Методология конструктивизма включает метод количественного исследования, как, например, метод гуманистической интерпретации социальных верований, разработанный Ежи Кмитой.

\section{Ключевые слова}

Антиглобальный протест, аксиологические предпосылки, этика, движения на низовом уровне, Глобальный договор ООН, сбалансированное и устойчивое развитие, индивидуальные и общие ценности.

Цитирование: Погоновска Б. Интерпретация антиглобальных социальных движений с точки зрения отражения этических аспектов экономики / Б. Погоновска // Вестник Тюменского государственного университета. Социально-экономические и правовые исследования. 2019. Том 5. № 3 (19). С. 8-22.

DOI: $10.21684 / 2411-7897-2019-5-3-8-22$ 
DOI: $10.21684 / 2411-7897-2019-5-3-8-22$

\section{СПИСОК ЛИТЕРАТУРЫ}

1. Bendyk E. Archipelag Kukiza / E. Bendyk, M. Mazuś // Polityka. 2015. No 21 (3010). 20 мая.

2. Czarna księga polskich artystów / под ред. K. Górna, K. Sienkiewicz, M. Iwański, K. Szreder, S. Ruksza и J. Figiel. Warsaw: Wydawnictwo Krytyka Polityczna, 2011.

3. Czas horroru. The interview of J. Żakowski with prof. Czapliński / J. Żakowski // Polityka. 2015. 29 июля - 4 августа. No 31.

4. Czasem trzeba przegrać wybory, żeby wygrać jutro. The interview of M. Stasiński with Javier Cercas / M. Stasiński // Gazeta Wyborcza. 2015. 6-7 июня.

5. Domosławski A. Chilijscy oburzeni: nie będzie barykad, tylko systematyczna praca /

A. Domosławski. 2014. URL: http://www.krytykapolityczna.pl/artykuly/ameryka-lacinska/20140423/chilijscy-oburzeni-nie-bedzie-barykad-tylko-systematyczna-praca (дата обращения: 11.10.2019).

6. Drozda J. Paradygmat emancypacyjny? O możliwym nowym zwrocie w polskim kulturoznawstwie inspirowanym tradycją CCCS / J. Drozda // Kultura Popularna. 2014. No 1/39. URL: http://www.academia.edu/8614010/PARADYGMAT EMANCYPACYJNY_O_mo\%C5\%BCliwym_nowym_zwrocie_politycznym_w_polskim_kulturoznawstwie_inspirowanym_tradycj\%C4\%85_CCCS (дата обращения: 5.06.2019).

7. Durrmeyer S. Stephane Hessel. Ojciec oburzonych / S. Durrmeyer, J. Biernat // Newsweek. 2012. URL: https://www.newsweek.pl/swiat/stephane-hessel-ojciec-oburzonych/ p2m0wnx (дата обращения: 11.10.2019)

8. Foucault M. Filozofia. Historia. Polityka. Wybór pism / M. Foucault. Warsaw: Wydawnictwo Naukowe PWN, 2002.

9. Foucault M. The Order of Discourse / M. Foucault. 2002. URL: https://www.kit.ntnu.no/ sites/www.kit.ntnu.no/files/Foucault_The\%200rder\%20of\%20Discourse.pdf (дата обращения: 9.12.2019).

10. Giddens A. Sociology / A. Giddens. 2009. URL: https://ia600206.us.archive.org/15/ items/Sociology_6_edition/Sociology_6_edition.pdf (дата обращения: 9.12.2019).

11. Hessel S. 2011. Indignez-vous! Get angry! Cry out! / S. Hessel. URL: http://indignez-vous-indignacion.blogspot.com/p/english.html (дата обращения: 9.12.2019).

12. Misztal B. A. Trust in Modern Societies. The Search for the Bases of Social Order / B. A. Misztal. 1998. URL: https://pdfs.semanticscholar.org/0602/5cfa3cb67675dd1cb65f a48753ede5211163.pdf?_ga=2.203289489.1674834713.15760752171253012239.1576075217 (дата обращения: 10.12.2019).

13. O Madagaskarze napisze ktoś inny. The interview of Misza Tomaszewski with Artur Domosławski / Z. Różycka // Kontakt. 2014. http://magazynkontakt.pl/wp-content/ uploads/2014/12/Kontakt-26_Zielone-pojecie.pdf (дата обращения: 11.10.2019).

14. Emancipate // Oxford Learner's Dictionary. URL: www.oxfordlearnersdictionaries.com/ definition/english/emancipate (дата обращения: 10.07.2019). 
15. Pałubicka A. Gramatyka kultury europejskiej / A. Pałubicka. Bydgoszcz: Oficyna Wydawnicza Epigram, 2013.

16. Polska budzi się 40 lat za późno. The interview of Michał A. Zieliński with Jan Sowa / M. A. Zieliński // Gazeta Wyborcza. 2015. Суббота-воскресенье 2-3 мая.

17. Poznań to nie Facebook. Z. Bauman in the interview with M. Danielewski and M. Wybieralski / M. Danielewski, M. Wybieralski // Gazeta Wyborcza. 2012. 7 декабря.

18. Power to the Cities. The interview with Richard Florida / J. Żakowski // Niezbędnik Inteligenta Polityka. 2012. No 1. Special edition. Pp. 116-120.

19. Rębała M. Oburzeni młodzi Francuzi zarywają noce / M. Rębała, K. Wyrzykowska // Gazeta Wyborcza. 2016. 26 апреля.

20. Standing G. The Precariat. The New Dangerous Class / G. Standing. 2011. URL: https://www.hse.ru/data/2013/01/28/1304836059/Standing. The_Precariat_The New_Dangerous_Class__BlooStanding (дата обращения: 9.12.2019).

21. Sztompka P. 2002. Socjologia / P. Sztompka. Kraków: Wydawnictwo Znak.

22. Turcja: Zamknięty dostęp do placu Taksim w Stambule. Dzisiaj rocznica protestów // Gazeta Prawna. 2015. 31 мая. URL: http://www.gazetaprawna.pl/artykuly/874680,turcjazamkniety-dostep-do-placu-taksim-w-stambule-dzisiaj-rocznica-protestow.html (дата обращения: 11.10.2019).

23. The Ten Principles of the UN Global Compact / UN Global Compact. URL: https://www.unglobalcompact.org/what-is-gc/mission/principles (дата обращения: 8.06.2019).

24. Uslaner E. 2003. The Moral Foundations of Trust / E. Uslaner. URL: https://www.researchgate.net/publication/228191342_The_Moral_Foundatio_of_Trust (дата обращения: 9.12.2019).

25. Валигора А. Социальное предпринимательство против свободного рынка. Типология (недостаточного) взаимодействия между субъектами социальной экономики и предприятиями / А. Валигора // Вестник Тюменского государственного университета. Социально-экономические и правовые исследования. 2019. Том 5. № 1. С. 23-35. DOI: 10.21684/2411-7897-2019-5-1-23-35

26. Winnicka E. Cztery pory oburzenia / E. Winnicka // Niezbędnik Inteligenta. Polityka. 2012. No 1. Special edition.

27. Žižek S. Occupy Wall Street: what is to be done next? / S. Žižek. 2012. URL: https:/www.theguardian.com/commentisfree/cifamerica/2012/apr/24/occupy-wall-streetwhat-is-to-be-done-next (дата обращения: 9.12.2019). 